DOI: https://doi.org/10.24144/2409-6857.2019.1(53).207-211

УДК: 657.2.016

Ганусич В.О., Шеверя Я.В.

\title{
ВИЗНАЧЕННЯ ЗМІСТУ ТА МІСЦЯ ЕКОЛОГІЧНОГО ОБЛІКУ В СИСТЕМІ УПРАВЛІННЯ СТАЛИМ РОЗВИТКОМ
}

\begin{abstract}
У статті розглянуто підходи до визначення екологічного обліку вітчизняними вченими та у міжнародній практиці. У вітчизняній науц̧і домінує розуміння ц̧ього поняття як обліку процесу природокористування. При изьому ряд вчених не підтримує доцільність застосування терміну "екологічний облік", але погоджується $з$ необхідністю розвитку облікових процедур, націлених на відображення позитивних та негативних змін в оточуючому середовищі, спричинених господарською діяльністю підприємства. У міжнародній практиці екологічний облік розвивається на макро- та мікрорівні. На макрорівні екологічний облік інтегрований у Систему національних рахунків, мікрорівень - це екологічний облік суб'єктів господарювання. Запропоновано визначення екологічного обліку як системи спостереження, вимірювання і реєстрації процесів взаємодіі суб'єкта господарювання з навколишнім середовищем. Дані екологічного обліку частково формуються в рамках фінансового і управлінського обліку та доповнюються переліком своїх специфічних екологічних показників.
\end{abstract}

Ключові слова: екологічний облік, природні ресурси, навколишнє середовище, стійкий розвиток, система національних рахунків.

Постановка проблеми. Стратегічна мета сталий розвиток, вимагає суттєвих змін в усіх сферах економічної діяльності. Сучасний бухгалтерський облік і звітність не продукують весь спектр інформації, необхідної для управління цими процесами. Для розробки системи інформаційного забезпечення сталого розвитку в останній час генерується багато ідей, які з різних сторін розширюють рамки облікових процедур. Але повноцінний розвиток бухгалтерської науки можливий лише через системні зміни у теорії обліку. Впровадження екологічного обліку як важливої складової інформаційного забезпечення процесу сталого розвитку, в першу чергу, має торкнутися змін теоретичних облікових категорій: переорієнтація принципів, розширення об'єктів обліку та облікових вимірників, 3'ясування вимагають рівні, об'єкти, предмет і цілі екологічного обліку.

Аналіз останніх досліджень і публікацій. Вітчизняні вчені, зокрема I.В. Замула, В.С. Лень, О.М. Колівешко, Л.А. Сахно, О.І. Гриценко, Л.М. Пелиньо, активно працюють над з'ясуванням сутності екологічного обліку, окреслення

(C) Ганусич В.О., к.е.н, доцент кафедри обліку та аудиту Ужгородського національного університету, тел.: 050-372-26-22, e-mail: veronika.hanusych@uzhnu.edu.ua

Шеверя Я.В., к.е.н, доцент кафедри обліку та аудиту Ужгородського національного університету, тел.: 099-954-05-02, e-mail: yaroslav.sheverya@uzhnu.edu.ua його рамок та визначення ролі в управлінні сталим розвитком.

Сучасна облікова наукова думка рухається в бік подолання традиційних стереотипів, відбувається поступова зміна орієнтирів із суто економічних до економіко-соціальних та економіко-екологічних. Але погляди на місце екологічної складової у системі бухгалтерського обліку серед науковців суттєво різняться.

Формулювання цілей статті. Цілями статті $\epsilon$ розглянути місце екологічного обліку в Системі національних рахунків на макрорівні та у системі бухгалтерського обліку підприємства на мікрорівні; визначити зміст, предмети та основні об'єкти екологічного обліку.

Опис основного матеріалу дослідження. В умовах розвитку екологічної свідомості суспільства формується запит по визначенню екологічних показників діяльності підприємства. Інформаційною системою, в рамках якої вони можуть бути сформовані є бухгалтерський облік. Наразі він включає дуже обмежену кількість екологічних показників, але відбувається процес поступової екологізації обліку. На важливості цього напрямку розвитку бухгалтерського обліку наголошують вчені I.В. Замула [1], О.I. Гриценко [2] та інші. Але, наразі, серед вчених немає єдності щодо визначення сегменту обліку, який відповідатиме за збір екологічних даних. Переважають терміни: екологічний облік та облік природокористування.

В.С. Лень та Гливенко дають визначення екологічного обліку, як процесу розпізнавання, 
оцінки і передачі екологічної інформації, що дає можливість користувачам такої інформації компетентно приймати рішення i формувати судження [3, с.526].

Ключовим моментом цього визначення є збір і передача саме екологічної інформації зацікавленим користувачам. Застосування даного терміну не цілком коректне, якщо розглянути зміст поняття екології, що подається у словнику екологічних термінів [4], як науки про взаємовідносини, тварин, рослин і мікроорганізмів між собою та навколишнім середовищем. Суб'єкт господарювання не в змозі оцінювати екологію як стан рівноваги між усіма видами живих організмів в оточуючому середовищі, а може лише збирати ту сторону екологічної інформації яка безпосередньо пов'язана 3 його господарськими операціями. Тому більш влучними можна вважати визначення екологічного обліку, в яких, замість більш загальної категорії екологічної інформації, застосовується вужче - природокористування.

Так, Л.А. Сахно визначає екологічний облік на підприємстві як систему виявлення, вимірювання, реєстрації, накопичень, узагальнень, зберігань, обробок і підготовок релевантної інформації про діяльність підприємства в області природокористування 3 метою передачі іi1 внутрішнім i зовнішнім користувачам для ухвалення оптимальних рішень [5].

Близьким до нього по змісту є визначення: O.I. Гриценко, за яким екологічний облік - це система виявлення, вимірювання, реєстрації, узагальнення та зберігання інформації про діяльність підприємств в області природокористування 3 метою передачі ii користувачам для прийняття оптимальних управлінських рішень $[2$, с. 680], та Т.О. Кірсанової, на думку якої екологічний облік на підприємстві - це система виявлення, вимірювання, реєстрації, нагромадження, узагальнення, зберігання, оброблення та підготовки релевантної інформації про діяльність підприємства в галузі природокористування 3 метою передачі ii внутрішнім і зовнішнім користувачам для прийняття оптимальних рішень [6].

I.В. Замула цілком слушно пов'язує визначення екологічного напрямку в обліку 3 напрямами екологічної діяльності, серед яких виділяє:

- освоєння природних ресурсів, їх добування (або добування корисних копалин), використання, відтворення та охорона;

- негативний вплив на навколишнє природне середовище (забруднення повітря, води, грунтів, розміщення відходів);

- власне природоохоронна діяльність

підприємства як комплекс природоохоронних заходів. [1, с. 60-61]

Виходячи 3 цього, I.В. Замула визначає бухгалтерський облік екологічної діяльності суб' єкта господарювання як систему виявлення, вимірювання, реєстрації, накопичення, узагальнення, зберігання та передачі інформації користувачам про вплив діяльності суб'єкта господарювання на навколишне природне середовище [1, с. 62]. При цьому автор уникає терміну «екологічний облік», а застосовує термін «бухгалтерський облік екологічної діяльності».

Це обгрунтовано 3 точки зору змістового наповнення, але дещо дисонує міжнародною практикою, де широко застосовується термін "екологічний облік" (environmental accounting). Вiн направлений на досягнення цілей стійкого розвитку, передбачає визначення низки грошових та натуральних показників, які дозволяють на міжнародному, державному, регіональному рівні, а також на рівні окремих компаній ефективно проводити природоохоронні заходи, отримувати інформацію щодо стану, розподілу та споживання природних ресурсів.

У світовій практиці екологічний облік ведеться як на макро-, так і мікрорівні.

На макроекономічному рівні ведення екологічного обліку передбачене Системою національних рахунків (System of National Accounts (SNA)), в контексті якого природні ресурси оцінюються як частина національного багатства. Точний облік наявності і використання природних ресурсів, стану забруднення навколишнього середовища $\epsilon$ передумовою ефективного управління ними, більш раціонального споживання та дбайливого ставлення до екологічної рівноваги. Це дозволяє оперативно вживати заходи до подолання проблеми нестачі природних ресурсів та покращити умови життя людей [7].

Системою національних

рахунків обліковуються з одного боку - потоки товарів та послуг, $з$ другого - капітал як сукупність активів, які застосовуються для виробництва товарів i послуг. У цьому контексті, природне середовище розглядається як природний капітал, який $\epsilon$ безпосереднім учасником процесу розширеного відтворення, оскільки без його участі не можлива організація процесу виробництва товарів і послуг. Виходячи $з$ даного судження, і самі природні ресурси, і процеси їх споживання та здійснення впливу на стан навколишнього середовища в процесі економічної діяльності підлягають обліку аналогічно з іншими видами капіталу. [7] 
У ряді країн окремі компанії активно впроваджують елементи екологічного обліку, формуючи таким чином його мікрорівень. Так Міністерство навколишнього середовища Японії у 2002 році видало „Керівництво 3 екологічного обліку" [8], його цілями визначено стійкий розвиток, підтримка сприятливих відносин із суспільством, проведення ефективних природоохоронних заходів. Бухгалтерські процедури, запропоновані у керівництві, визначають методику обліку витрат на збереження навколишнього середовища у процесі звичайної діяльності, а також визначення доходів, отриманих від впровадження природоохоронних заходів. Керівництво описує способи визначення натуральних показників екологічного обліку та можливі підходи до їх грошової оцінки.

Враховуючи пріоритети екологічного обліку, які декларуються в міжнародних нормативних документах, та традиційні вітчизняні підходи по визначення бухгалтерського обліку, можна сформулювати наступне визначення: екологічний облік - це система спостереження, вимірювання і реєстрації процесів взаємодії суб'єкта господарювання з навколишнім середовищем.

Предметом екологічного обліку - $є$ екологічна сторона усіх господарських процесів, які відбуваються на підприємстві. Таким чином, об'єктами екологічного обліку будуть: екологічні активи, екологічні зобов'язання, екологічні доходи та екологічні витрати, які утворюються у процесі взаємодії суб'єкта господарювання 3 оточуючим середовищем. Щоб остаточно обгрунтувати доцільність застосування терміну «екологічний облік» (environmental accounting) у вітчизняній практиці, варто розглянути його місце:

- в інформаційному забезпеченні сталого розвитку на макрорівні (рис. 1);

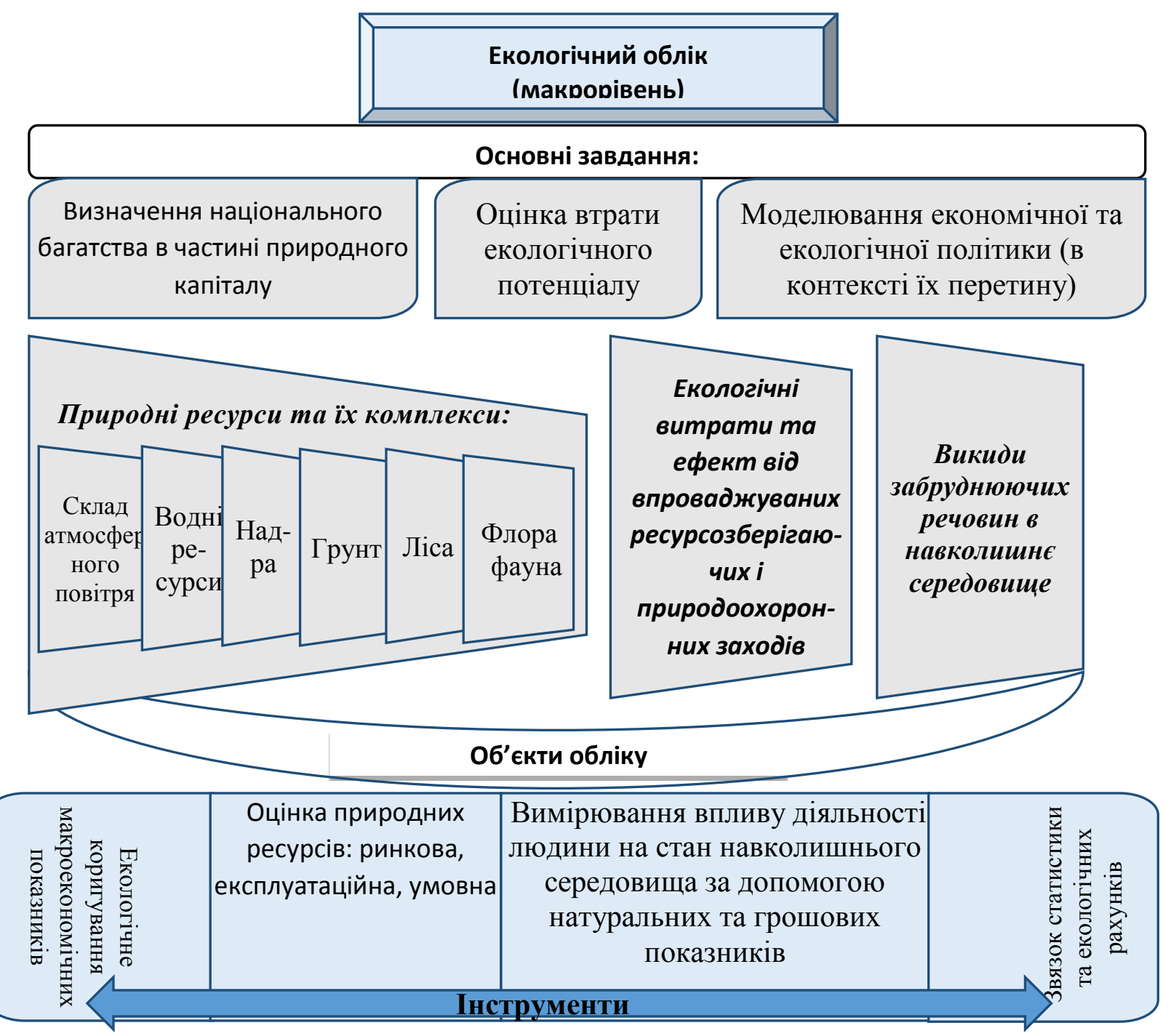

Рис 1. Завдання, об'єкти та інструменти інтегрованого економічного та екологічного обліку на макрорівні*

*Джерело: авторська розробка 


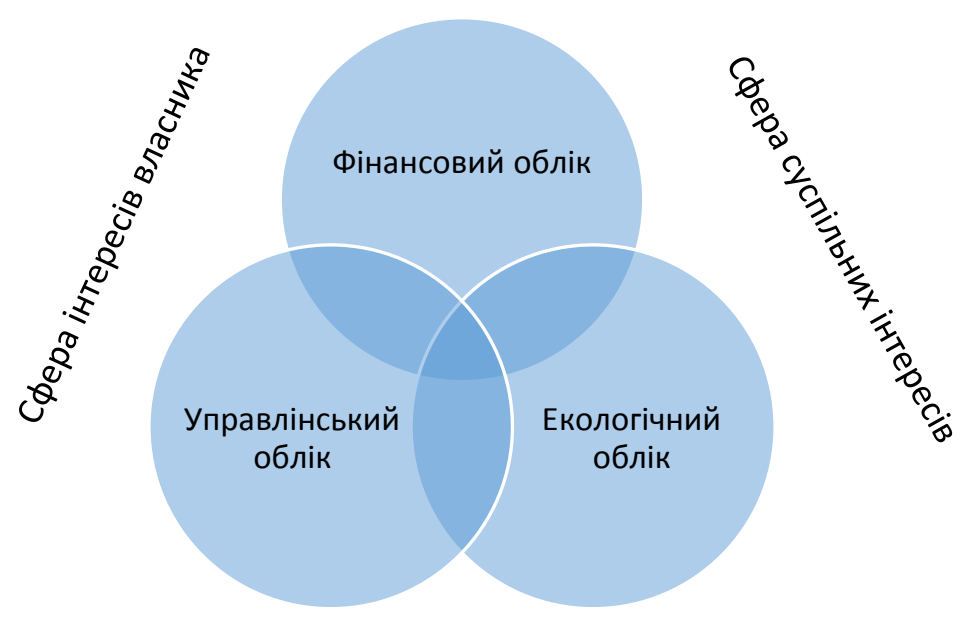

Рис. 2. Місце екологічного обліку серед традиційних видів бухгалтерського обліку* *Джерело: авторська розробка.

Основними завданнями екологічного обліку, інтегрованого в Систему національних рахунків на макрорівні $\epsilon$ (рис. 1):

- визначення національного багатства в частині природного капіталу;

- оцінка втрати екологічного потенціалу;

- моделювання економічної та екологічної політики (в контексті їх перетину).

Для досягнення цих завдань застосовують низку спеціальних інструментів:

- екологічне макроекономічних показників;

- оцінка природних ресурсів: ринкова, експлуатаційна, умовна;

- зв'язок статистики та екологічних рахунків;

- вимірювання впливу діяльності людини на стан навколишнього середовища за допомогою натуральних та грошових показників.

Комплексне застосування перерахованих інструментів до об'єктів обліку задля досягнення визначених завдань формує інтегрований економічний та екологічний облік на макроекономічному рівні (Integrated Environmental and Economic Accounting) (рис 1).

Дані екологічного обліку частково формуються в рамках фінансового i управлінського обліку та доповнюються переліком своїх специфічних екологічних показників (рис. 2). Необхідність визначення частини екологічних показників в рамках фінансового обліку неминуче призведе до трансформаційних змін у його об'єктах та методиках.

\section{Висновки і перспективи подальших досліджень.}

Реальні

процеси реформування бухгалтерського обліку лишаються осторонь підтримання концепції сталого розвитку. Передусім, це можна пов'язати 3 недосконалою методологічною базою. Зокрема облікові процедури, що стосуються природокористування та природоохоронних заходів, які розробляються вітчизняними та зарубіжними вченими наразі розрізнені та не мають спільного теоретичного підгрунтя. Визначення чітких орієнтирів розвитку екологічного обліку дозволить створити потужну повноцінну інформаційну базу управління сталим розвитком.

Метою запровадження екологічної складової облікового забезпечення процесу сталого розвитку є повне та об'єктивне відображення позитивного і негативного впливу господарської діяльності людини на зміни у кількісному та якісному складі природних ресурсів, забруднення навколишнього середовища, порушення екологічного балансу, а також відображення процесів раціонального природокористування та проведення природоохоронних заходів.

Екологічний облік може розглядатися як окрема підсистема загальної системи обліку, дані якого частково формуються у фінансовому та управлінському обліку, та визначатися як система спостереження, вимірювання i реєстрації процесів взаємодії суб'єкта господарювання 3 навколишнім середовищем. Подальшої деталізації потребує перелік об'єктів 
екологічного обліку i визначення його категоріального апарату; вивчення інформаційних зв’язків 3 традиційними видами і управлінського обліку в бік їх екологізації. обліку та трансформація показників фінансового

\section{ПЕРЕЛІК ВИКОРИСТАНИХ ДЖЕРЕЛ}

1. Замула I.В. Бухгалтерський облік екологічної діяльності у забезпеченні стійкого розвитку економіки: монографія / І.В. Замула. - Житомир : ЖДТУ, 2010. - 440 с.

2. Гриценко О.І. Екологічний облік: визначення перспектив та основних засад упровадження / О.І. Гриценко // Економіка і суспільство. - Мукачівський державний університет. - 2016. - Вип. 2. - с. 678-683.

3. Лень В. С. Класифікація видів обліку / В. С. Лень, В. В. Гливенко // Економіка: проблеми теорії та практики : зб. наук. праць. - Дніпропетровськ : ДНУ, 2003. - Вип. 186, т. 2. - С. 521-528.

4. Попович I.I. Словник екологічних термінів / I.I. Попович. - Акрешори: Писаний Камінь, 2010. // [Електронний pecypc] Режим доступу - https://evrika.if.ua/740/

5. Сахно Л.А. Екологічний облік і аудит в реформуванні традиційної системи обліку на підприємстві / Л.А. Сахно // Облік і фінанси АПК: бухгалтерський портал, 2009. - №1. - с. 89-92. // [Електронний ресурс] Режим доступу http://magazine.faaf.org.ua/ekologichniy-oblik-i-audit-v-reformuvanni-tradiciynoi-sistemi-obliku-na-pidpriemstvi.html 6. Кирсанова, Т.А. Экологический контроллинг- инструмент экоменеджмента: монография / Т.А. Кирсанова, Е.В. Кирсанова, В.А. Лукьянихин ; [под ред. В.А. Лукьянихина]. Сумы : Козацький Вал, 2004. - 222 с.

7. Integrated Environmental and Economic Accounting - An Operational Manual / Handbook of National Accounting Series F, No. 78 (United Nations publication United Nations publication Sales No. E.00.XVII.17), - 2000 // [Електронний ресурс] Режим доступу - https://unstats.un.org/unsd/publication/SeriesF/SeriesF_78E.pdf

8. Environmental Accounting Guidelines, Ministry of the Environment Government of Japan. - February 2005. // [Електронний ресурс] Режим доступу - https://www.env.go.jp/en/policy/ssee/eag05.pdf

\section{REFERENCES}

1. Zamula, I.V. (2010). Bukhghaltersjkyj oblik ekologhichnoji dijaljnosti u zabezpechenni stijkogho rozvytku ekonomiky [Accounting of ecological activity in ensuring sustainable development of the economy]. Zhytomyr: ZhDTU [in Ukrainian].

2. Ghrycenko, O.I. (2016). Ekologhichnyj oblik: vyznachennja perspektyv ta osnovnykh zasad uprovadzhennja [Environmental accounting: definition of the prospects and main principles of implementation]. Ekonomika i suspil'stvo -Economy and Society, 2, 678-683 [in Ukrainian].

3. Lenj, V. S., \& Ghlyvenko, V. V. (2003). Klasyfikacija vydiv obliku [Classification of types of accounting]. Ekonomika: problemy teorii i praktyky - Economics: problems of theory and practice, 186, 2, 521-528 [in Ukrainian].

4. Popovych, I.I. (2010). Slovnyk ekologhichnykh terminiv [Dictionary of environmental terms]. Akreshory: Pysanyj Kaminj [in Ukrainian].

5. Sakhno, L.A. (2009). Ekologhichnyj oblik i audyt v reformuvanni tradycijnoji systemy obliku na pidpryjemstvi [Environmental accounting and auditing in the reform of the traditional accounting system at the enterprise]. Oblik $i$ finansy APK - Accounting and finance of agroindustrial complex, 1, 89-92 [in Ukrainian].

6. Kirsanova, T.A., \& Kirsanova, E.V., Luk'yanikhin, V.A. (2004). Ekologicheskiy controlling - instrument ekomenedzhmenta [Ecological controlling is an environmental management tool]. Sumy: Kozatskiy Val [in Ukrainian].

7. Integrated Environmental and Economic Accounting - An Operational Manual (2000). unstats.un.org. Retrieved from: https://unstats.un.org/unsd/publication/SeriesF/SeriesF_78E.pdf [in English].

8. Environmental Accounting Guidelines, Ministry of the Environment Government of Japan (2005). www.env.go.jp. Retrieved from: https://www.env.go.jp/en/policy/ssee/eag05.pdf [in English]. 